\title{
Chemical Characteristics and Sensory Properties of Novel Snacks Produced with Okara Fortified with Omega-3 from Fish Oil
}

\author{
Trinidad Sandra Álvarez ${ }^{\mathrm{a}}$ and Daniela Lorena Lamas ${ }^{b^{*}}$ \\ ${ }^{a}$ Facultad de Ciencias Exactas y Naturales, FACEN - Universidad Nacional de Asunción, UNA, Asunción, \\ Paraguay - Consejo Nacional de Ciencia y Tecnología (CONACYT). Mar del Plata, Buenos Aires, Argentina \\ ${ }^{\mathrm{b}}$ Instituto de Investigaciones Marinas y Costeras (IIMyC), CONICET- Consejo Nacional de Investigaciones \\ Científicas y Técnicas UNMdP, Instituto Nacional de Investigación y Desarrollo Pesquero. Mar del Plata, \\ Buenos Aires, Argentina \\ ${ }^{*}$ Corresponding author \\ dlamas@inidep.edu.ar \\ TEL.: +54-223-420-9100
}

Received: 4 February 2019; Published online: 24 February 2021

\begin{abstract}
The aim of the present work was to develop a new soy-based food product and evaluate its chemical and sensory properties. A soy-based snack was mixed with rice (Oryza sativa), fortified with eicosapentaenoic acid (EPA) and docosahexaenoic acid (DHA) Omega-3 fatty acids from fish by-products in encapsulated and emulsion form. Soy beans were subjected to grinding processes, maceration in pure distilled water, filtration and pasteurization, to obtain vegetable drinks and generate solid residue. Finally, a sensory analysis of the product obtained was carried out. The snacks protein content was around $17 \%$. From the sensory evaluation, it could be concluded that the snacks with $50 \%$ of okara had great acceptability and the addition of Omega- 3 was also acceptable. So, okara represents an excellent raw material that can be utilized for dietary protein fortification. On the other hand, it proposes based on soy and fish by-products allow sustainable development and contribute to the economy of each sector.
\end{abstract}

Keywords: Okara, soybean by-product; Sensory analysis; Protein; Omega-3

\section{Introduction}

Currently, consumers are becoming aware of the importance of diet in relation to health problems. Snacks foods as a cereal-based product, are the most commonly consumed and are an important source of starch and other dietary carbohydrates (dietary fibre), which play an important role in the energy requirement and nutrient intake of human. However, these cereal-based products tend to be lower in certain nutrients including protein (Meng, Threinen, Hansen \& Driedger, 2010;
Rhee, Kim, Kim, Jung \& Rhee, 2004). As a result, demand for a snack with enhanced nutrition exists (Navam, Tajudini, Srinivas, Sivarooban \& Kristofor, 2014). Many researchers have studied health-promoting snacks that use buckwheat (Dapčević Hadnađev, Torbica \& Hadnađev, 2013), barley (Frost, Adhikari \& Lewis, 2011) wheat flour, and millet (Verma \& Patel, 2013). The idea of developing products using a mixture of cereals and legumes to combat hunger and malnutrition problems in developing countries is a long-standing one. Soybean cultivars 


\section{Nomenclature}

PUFAs polyunsaturated fatty acids

EPA eicosapentaenoic acid

DHA docosahexaenoic acid
CMC carboxymethylcellulose

Fish oil $\mathrm{C}$ encapsulated fish oil

Fish oil E Emulsion of fish oil vary in their crude protein and lipid contents, lipoxygenase activities and fatty acid compositions (Vong \& Liu, 2016). Previous works reported that protein content of soybean range from 42 to $48 \%$ (Guimaraes et al., 2018; Kanojia, Singh, M. Khandelwal \& Azam, 2016). Due to its high protein content, polyunsaturated linoleic acid and isoflavones, soybean is qualified as a functional food (Guimaraes et al., 2018). This fact has generated great interest from food industry to incorporate ingredients from soybean into products that provide beneficial properties to the organism and which are called "functional foods" (Genovese \& Lajolo, 2002).

On the other hand, soymilk and tofu manufacturing produce great amounts of residue called okara. This is considered a waste by-product and it is disposal, due to the high water, is an important environmental concern (Waliszewski, Pardio \& Carreon, 2002). Dry okara, which contains about $50 \%$ dietary fiber, $25 \%$ protein and $10 \%$ lipid (Li et al., 2013), is an excellent alternative for incorporation into food products, not only as a form of food enrichment, but also as a way of using and valuing this residue (Vong \& Liu, 2016).

Also, several clinical studies showed the association of soy foods with reduction in blood serum cholesterol levels, risk of cardiovascular diseases in humans, mammary and prostate cancers in women and men, respectively, osteoporosis among menopausal women and increased bone density (Messina \& Loprinzi, 2001). Beneficial effects, such as prevention of diabetes and obesity, protection against intestinal and renal diseases, related to the promotion of human health and nutrition, were also reported by
Friedman and Brandon (2001). The fortification of foods with PUFAs of the Omega- 3 series is a current issue of interest. The daily intake of these compounds in populations of developed countries is below the recommended dose (Ferguson, Smith \& James, 2010; Iafelice et al., 2008). Among the health benefits associated with the intake of these fatty acids are the reduction of cardiovascular diseases, anti-inflammatory, anti-allergic effects, good development and function of the brain, the retina and the nervous system, and the potential protection against certain types of cancer (Iafelice et al., 2008; Kolanowski \& Weissbrodt, 2008). As well, there are studies that suggest that the consumption of Omega-3 during pregnancy can have a good influence on the foetus (Yupa \& Claribel, 2015). In recent years, worldwide, the number of available foods fortified with PUFAs has increased rapidly in an attempt to address this deficiency. However, there are no studies on fortification of soy snacks. Thus, the incorporation of fatty acids of the Omega- 3 series could be an extra factor to the benefits of them. Hence, the overall objective of this work was to develop a snack with soybean (Glycine max) okara to achieved a high protein content, along with rice (Oryza sativa) and improved it nutritional value by using Omega-3 from fish byproducts in encapsulated and emulsion form. In addition to that, the chemical characteristics and the effect of adding Omega- 3 to the product sensory preference were determined. Sensory properties were evaluated in terms of overall visual and taste acceptability of the products. 


\section{Materials and Methods}

\section{$2.1 \quad$ Materials}

The oilseeds were obtained commercially from Vivo and Sano, (Ciudad del Este, Paraguay). They were received in polyethylene bags and stored free of oxygen, light and moisture at room temperature, until their use.

All materials and reagents for making capsules, beverages and snacks were food grade. Citric acid, calcium chloride and guar gum were commercially purchased from KUBO Company and sodium alginate was obtained from Química Bolívar. The orange flavouring, stevia, carboxymethylcellulose and a mix of whole seeds with sunflower, black and white sesame, chia and squash were purchased in commercial stores of Mar del Plata city (Argentina). Ray liver oil was provided by OmegaSur S.A. (Mar del Plata, Argentina) and the average Omega-3 PUFA content was $158 \mathrm{mg}$ g-1, being the EPA and DHA 43 and $115 \mathrm{mg}$ respectively. In addition, soybean oil was provided by Cargil S.A. (Bahía Blanca, Argentina).

All the reagents used for the determinations were of analytical grade and high purity.

\subsection{Physicochemical characterization}

To characterize the seeds, 3 sub-lots of them containing 10 seeds each were weighed and their average weight was calculated. The transversal length was calculated in the same way.

The proximate composition on raw and snacks products was determined according the methods of the Association of Official Analytical Chemists (AOAC, 1990).

Moisture was quantified by drying in a furnace at a temperature of $105{ }^{\circ} \mathrm{C}$ to constant weight (AOAC, 1990). The ashes were determined by calcination in muffle at $550{ }^{\circ} \mathrm{C}$ of temperature, until obtaining white ash and constant weight (AOAC, 1990). The proteins were determined by the Kjeldahl method using the conversion factor 5.70 AOAC (1984). For the snacks the conversion factor used was 5.70 and 5.95 to soy and rice respectively, according to the proportions estab- lished in the formulations. The determination of fats was carried out by Randall (1974) method and lipids were extracted and quantified by the method of Bligh and Dyer (1959). Crude fibre was estimated by gravimetric treatment (AOAC, 1990). Carbohydrate contents were calculated by difference.

To determine the fatty acid profile of the lipid fraction, it was subject to methylation and subsequent gas chromatography (ISO 12966-2, 2011). Briefly, $60 \mathrm{mg}$ of lipid sample was mixed with $2 \mathrm{ml}$ of hexane and $0.3 \mathrm{ml}$ of $\mathrm{KOH} / \mathrm{MeOH}$ reagent in a glass tube in order to convert fatty acids to methyl esters (FAMEs). The sample was mixed vigorously; then, $2 \mathrm{ml}$ of $\mathrm{NaCl}$ and 2 $\mathrm{ml}$ of hexane were added and mixed again. The sample was allowed to stand for 5 minutes, and the upper hexane layer was separated and transferred to a clean tube. The FAMEs were determined with a Shimadzu GC2010 (Kyoto, Japan) equipped with a flame-ionization detector (260 ${ }^{o} \mathrm{C}$ ) and capillary column (30 m x $0.32 \mathrm{~mm} ; 0.25$ $\mu \mathrm{m}$ film thickness; Omegawax 320, Darmstadt, Germany). A split injector (50:1) at $250{ }^{\circ} \mathrm{C}$ was used. The column temperature was programmed starting at a constant temperature of $120^{\circ} \mathrm{C}$ during $20 \mathrm{~min}$, heated to $200^{\circ} \mathrm{C}$ at $1^{\circ} \mathrm{C}$ minute ${ }^{-1}$, held at $200{ }^{\circ} \mathrm{C}$ during 1 minute, heated again to $220{ }^{\circ} \mathrm{C}$ at $5{ }^{\circ} \mathrm{C} / \mathrm{min}$, and finally held at $220{ }^{\circ} \mathrm{C}$ for 20 minutes. The separation was carried out with nitrogen as carrier gas. The oven temperature was increased to $240{ }^{\circ} \mathrm{C}$ at a rate of $5{ }^{\circ} \mathrm{C}$ minute $^{-1}$ and held for 5 minutes. A volume of 1 $\mu \mathrm{L}$ of sample was manually injected (in duplicate), and FA peaks were identified by comparison of their retention times with those of external reference standards (Supelco FAME Mix C4-C24, Pennsylvania, USA). Retention times and peak areas were processed by Shimadzu GC Solution software.

The calories of snacks were determined considering all the ingredients used in the formulation (expressed in grams) and their corresponding quantities. Finally, the conversion of grams to calories was performed. For nutritional labelling, the US Food and Drug Administration (FDA) suggests caloric content be calculated by a procedure using 4,9 , and 4 calories gram $^{-1}$ of protein, fat, and carbohydrate, respectively. 


\subsection{Formulations of soy snacks}

Soybeans were sorted, and once the broken and immature ones were removed, the rest were washed. Next, wet okara was obtained according to the protocol described by Turhan, Temiz and Sagir (2007) with modifications. Soybeans (100 g) were soaked for 12 hours at room temperature in $600 \mathrm{ml}$ of distilled water. Then, the hydrated soybean was drained by rinsing hot water (90$95^{\circ} \mathrm{C}$ ), and cooking was done to inactivate the lipoxygenase enzyme and the antitrypsin. The bitter water was removed. The milling was done in a domestic mill (Philips) and the process time was standardized to 3 minutes. After washing, the slurry was filtered through cheesecloth and pressed obtaining the residue called okara. Fig. 1 illustrated the sequence of soymilk processing steps and the obtaining fresh okara to manufacture the snacks.

The following ingredients were used for the production of snacks: okara rice flour, carboxymethylcellulose, soybean oil, stevia, fish oil in capsule and emulsion form and a mix of whole seeds, sunflower, sesame. Six formulations were developed and each one was identified as G code with the numbers from 1 to 6 . Table 1 summarizes the percentage distribution of the components of each one and Fig. 2 shows the mixtures prepared. The mixtures were kneaded and brought to $4 \mathrm{~mm}$ in thickness, cut into a circular shape of $2.5 \mathrm{~cm}$ in diameter and baked at $170{ }^{\circ} \mathrm{C}$ for 20 minutes. Once baked, they were cooled to room temperature.

\subsection{Preparation of Omega-3 capsules}

For the fish oil encapsulation process, sodium alginate was dispersed in distilled water and allowed to stand overnight at room temperature for complete hydration of the biopolymer. Then the discontinuous emulsion (10 g) was prepared which was formulated with a 1: 2 ratio of oil phase dispersed to continuous phase. The preemulsion was obtained by homogenization of medium speed during 2 minutes using an Ultraturrax (Omni Mixer, Germany). The emulsification was carried out by centrifuging at $3500 \mathrm{rpm}$ for 35 minutes. Finally, the capsulates were obtained by dripping the mix in $0.1 \mathrm{M} \mathrm{CaCl}_{2}$ solution and dried at $30{ }^{\circ} \mathrm{C}$ for 24 hours in stove and 7 days in desiccator.

\subsection{Sensory analysis of formulated foods}

The sensory attributes of okara were analysed by 16 untrained panellists (men and women, 25 to 65 years old). Colour, aroma, flavour and texture of the 3 snacks formulated with equal proportion of okara and rice flour were evaluated. The samples were served in polystyrene dishes coded with letters. They were presented in individual sectors, with good natural light and a temperature of $23{ }^{\circ} \mathrm{C}$. The analysis was performed on portions of $10 \mathrm{~g}$ each. The participants were instructed to eat a snackand drink water between the samples in order to cleanse the palate if it was necessary. The panellists evaluated the acceptance of the samples using a hybrid hedonic scale of 9 points (Drake, 2007), where $1=$ I was very upset, and $9=\mathrm{I}$ liked it extremely. There was a space for observations and comments. Then a descriptive sensory analysis was carried out using different descriptors. The panellists were previously instructed in the descriptors used in this study like flavour as (soybean, to rice, to fish, sweet or salty), odour (to bean soy, to rice, fish smell, without define odour) colour (brownish, green, whitened) and oral texture (hard, crispy, humid, soft, dry). Then, two discriminatory and preference test were made between these three snacks and then one among the snacks enriched with capsules and emulsions. The panellists evaluated each treatment individually on the individual score sheets. For a preference test, the panellists were also provided a "your preference" sheet to indicate which snack they preferred and to briefly discuss why. During the instructed, the difference between a descriptive and a preference test was clearly explained. The purpose of including a preference test was also discussed with the panellists. Finally, a general product acceptance questionnaire was developed in order to achieve a sensory profile of the product. The analysis was performed 48 hours after the product was prepared. 


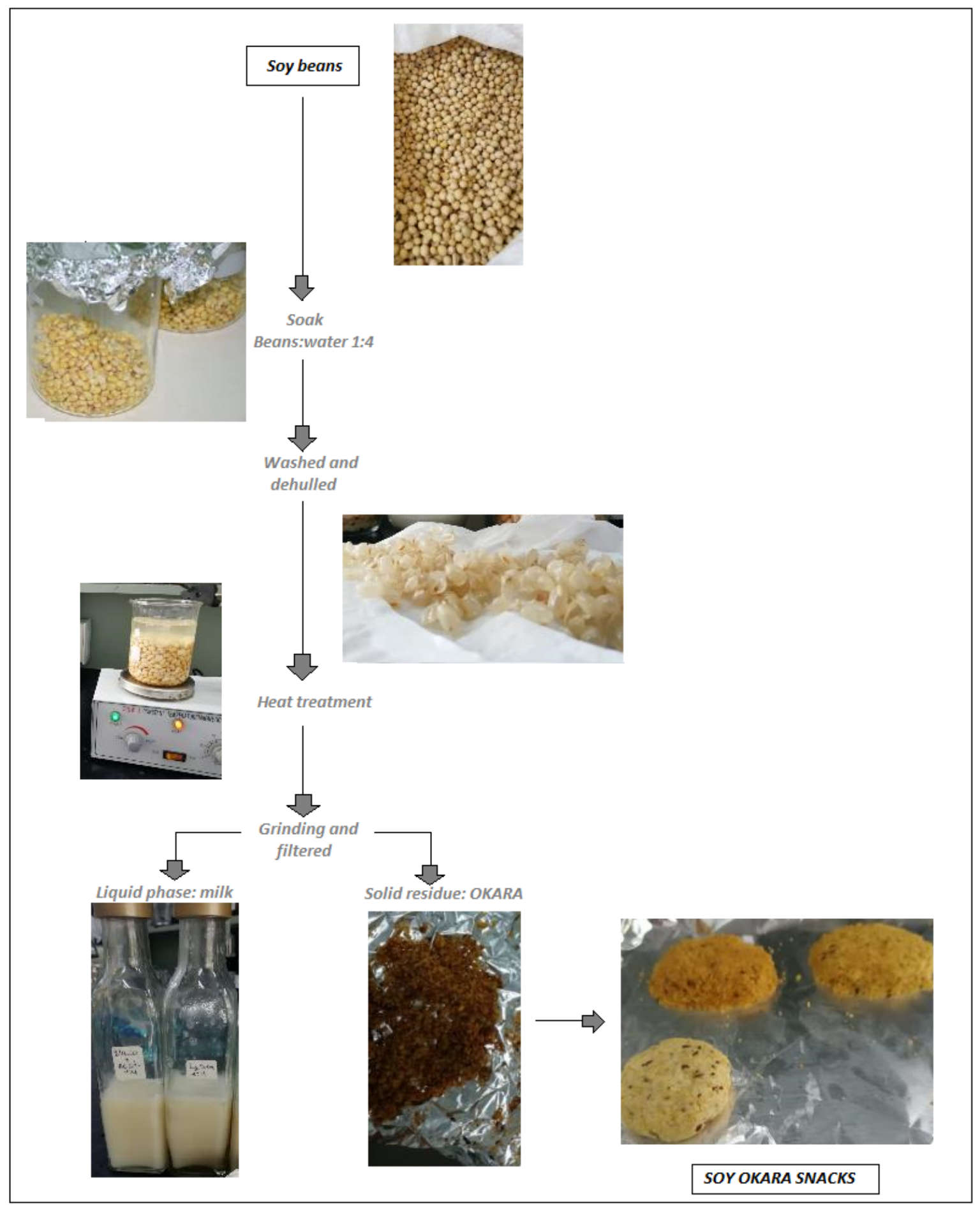

Figure 1: Generation of okara from the manufacture of soy milk

IJFS | February $2021 \mid$ Volume $10 \mid$ pages SI82-SI94 
Novel Snacks produced with Okara fortified with Omega-3 |SI87

Table 1: Formulation of okara snacks

\begin{tabular}{lcccccc}
\hline & \multicolumn{7}{c}{ Sample } \\
\hline Ingredient g\% & G1 & G2 & G3 & G4 & G5 & G6 \\
\hline Okara & 40 & 36 & 24 & 5 & 24 & 24 \\
Rice flour & 0 & 4 & 24 & 44 & 24 & 24 \\
CMC & 18.2 & 18 & 15 & 15 & 15 & 14 \\
Soy oil & 19.2 & 19 & 17 & 17 & 17 & 17 \\
Stevia & 1 & 1 & 1 & 1 & 1 & 1 \\
Distilled water & 18.2 & 18.4 & 15 & 15 & 14 & 15 \\
Seed mix & 3 & 3 & 4 & 3 & 4 & 4 \\
Fish oil C & 0 & 0 & 0 & 0 & 1 & 0 \\
Fish oil E & 0 & 0 & 0 & 0 & 0 & 1 \\
\hline
\end{tabular}

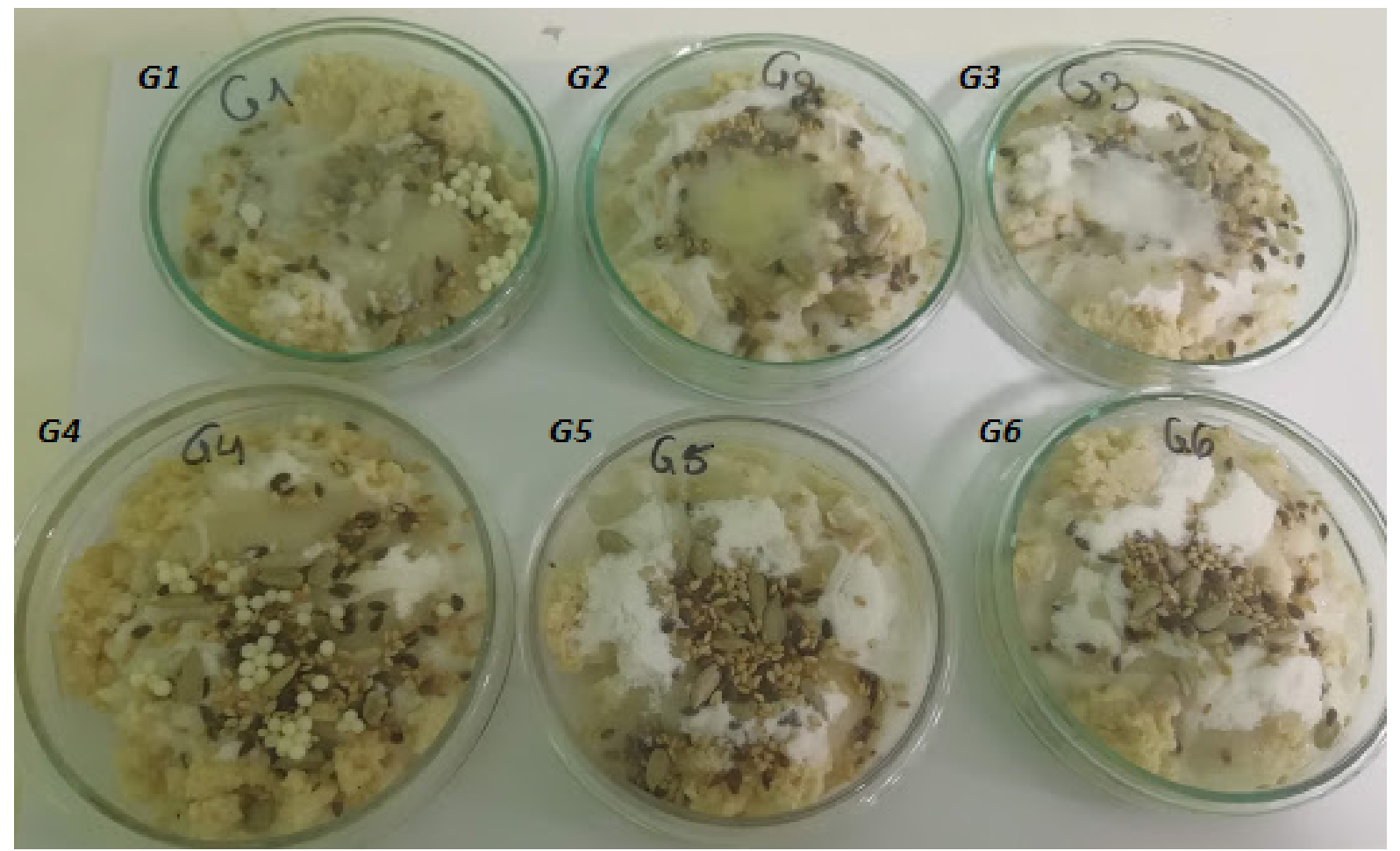

Figure 2: Mixture of ingredients with different okara levels for snacks. G1 40\% okara; G236\% okara; G3 $24 \%$ okara; G4 5\% okara; G5 24\% okara, G6 24\% okara 


\subsection{Statistic analysis}

All analyses were performed in duplicate, and were expressed as mean value \pm standard deviation. The difference between the mean values was evaluated by the Duncan test, and it was considered significant with a $\mathrm{P}$ value of $5 \%$. For the statistical analysis we used the Infostat (2017) software, of general application developed under the Windows platform.

\section{Results and Discussion}

\subsection{Proximate composition of the raw material}

Soybeans were accepted according the maturity requirements and health conditions established by (Guzman Tituaña, 2018). The total lipid content was $65.1 \%$, with $7.1 \%$ protein, $4.7 \%$ ash and moisture $2.12 \%$. Table 2 shows the fatty acid profile of the lipid fraction of soybean oil. It can be seen that the content of linoleic acid is the highest, followed by oleic and palmitic. These results are consistent with bibliography data for soybean oils (O'Brien \& Timms, 2004).

Fresh okara was obtained as by-product of soybean milling and aqueous fraction extraction for producing soydrink. Immediately it was weighted and dried at $60{ }^{\circ} \mathrm{C}$ during overnight. The moisture content was $79.11 \%$ and it was corroborate with the ones reported by Wachiraphansakul and Devahastin (2007) (75-80 $\%)$, He and Chen (2013) (80\%) and by Tie Su, Pedroso Yoshida, Contreras-Castillo, Quinones and Venturini (2013) (80 \%). By this way, okara spoilage during storage and processing was avoided maintaining characteristic flavour and colour. Mean proximate analysis of the dried samples were as follows: protein $38.37 \mathrm{~g} \mathrm{\%}$, fat $15.13 \mathrm{~g} \%$, fiber $35.74 \mathrm{~g} \%$, total carbohydrates $7.65 \mathrm{~g} \mathrm{\%}$ and ash $3.11 \%$. These data are in accordance with values reported by Waliszewski et al. (2002) for different okara samples. Similar results of protein content were previously reported by Ostermann-Porcel, QuirogaPanelo, Rinaldoni and Campderros (2017). Also, Katayama and Wilson (2008) reported similar values for the commercial dried okara powder.
One of the reasons for the wide use of soy protein in foods is its high quality (measured according to PDCAAS Protein Digestibility-Corrected Amino Acid score and defined by FAO/WHO (2011). It has been demonstrated that the amino acid content added to its high bioavailability qualifies it with the highest value (1 or $100 \%$ ) equalling in quality the whey, casein and albumin proteins (Vanegas Perez, Restrepo Molina \& Lopez Vargas, 2009). On the other hand, some beneficial health effects have been attributed to soy protein as hypocholesterolemic and hypotriglyceridemic actions (Tovar et al., 2002). Also, some specific clinical conditions require nutrition based on soy, as immunoglobulin Emediated milk allergy; post infectious diarrhoea due to lactose intolerance; galactosaemia; and other cases as the use as a vegan human milk substitute; and treatment of common feeding problems such as fussiness, gas, and spit-up, mainly in infants (Merritt \& Jenks, 2004). However, the food industry in many cases prefers to replace whey, casein and albumin proteins by soy protein, not only for health reasons but also for costs (Hoogenkamp, 2007; USDA, 2007).

\subsection{Formulation and making the snack. Physicochemical and caloric value}

The early recipes in this study involved ingredients and processing modifications to produce the proper flavour and texture. When the dough was constituted by okara ratio more than $50 \%$, the products broke apart into crumbs. When the okara and rice were added in the same ratio, products formulated resulted with less ligation problems. Major rice content produced a cake snack without a pleasant airy texture.

All the snacks formulated were analysed in terms of their chemical and caloric properties. However, only the snacks formulated with the same content of rice and okara were submitted for sensory analysis. Data on the chemical composition of snacks are presented in Table 3. The values obtained are within the ranges expected for this type of products. Moisture values are in accordance with the water content added in each case. In addition, these values are in agreement 
Novel Snacks produced with Okara fortified with Omega-3 |SI89
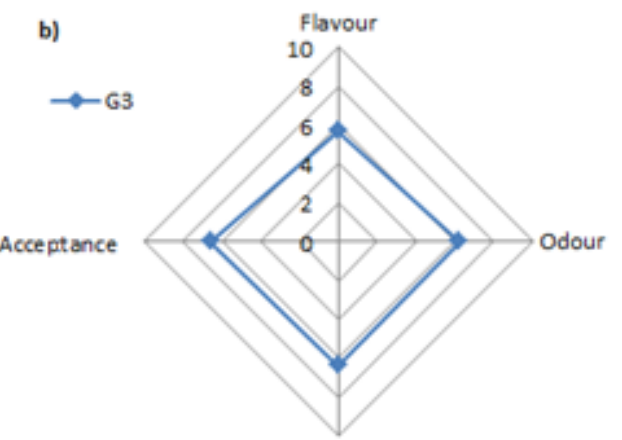

a)
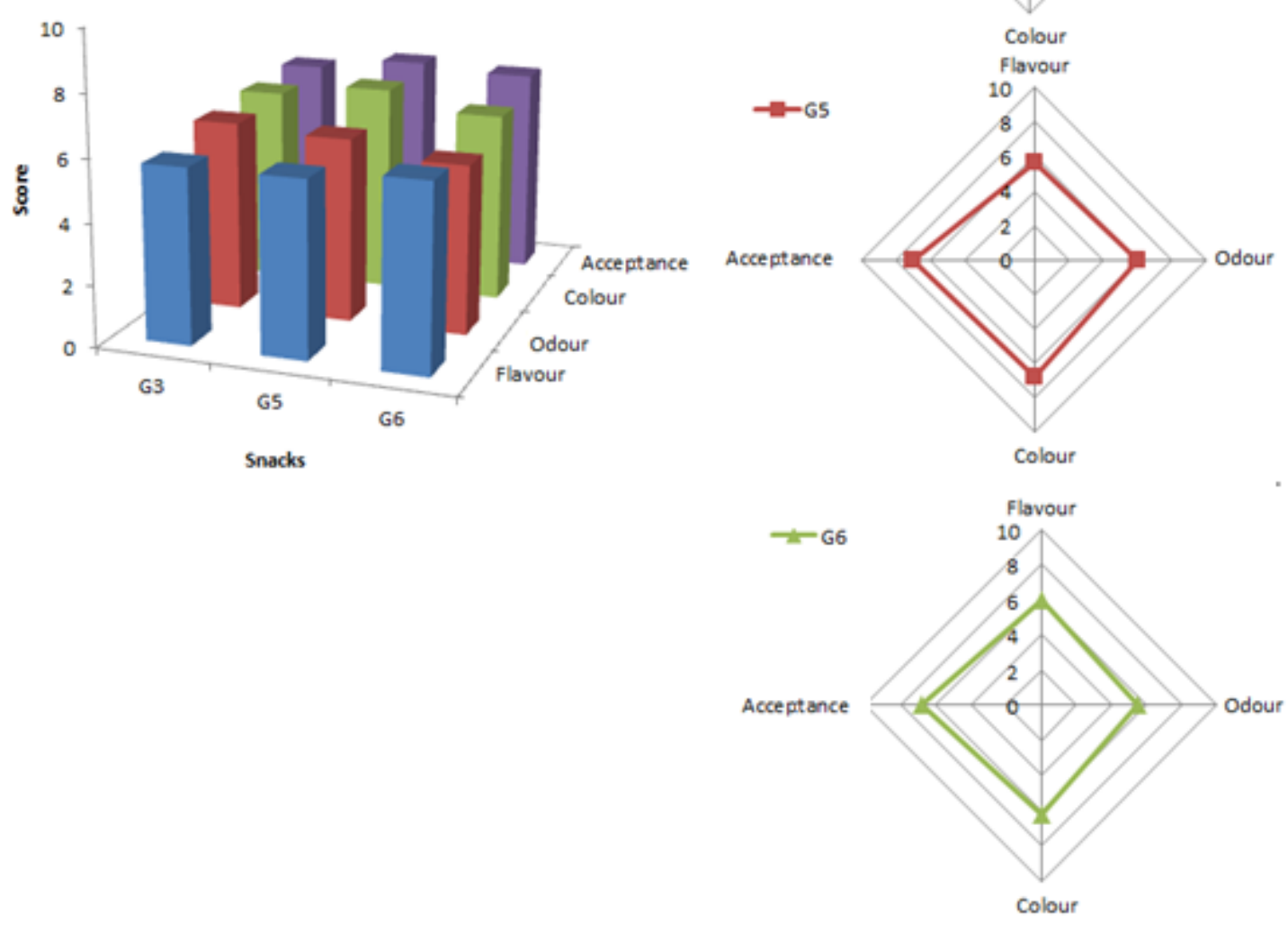

Figure 3: Sensory assessment. a) The score distribution of the three snacks studied. b) The descriptive profile of the attributes of each sample 
Table 2: Fatty acid composition of soybean oil using Gas Chromatography

\begin{tabular}{|c|c|}
\hline Fatty acid & Soy oil (\%) \\
\hline $16: 00$ & $10.21 \pm 0.35$ \\
\hline $18: 00$ & $4.05 \pm 0.04$ \\
\hline 20:00 & $0.19 \pm 0.01$ \\
\hline $22: 00$ & $0.19 \pm 0.02$ \\
\hline$\sum \mathrm{SFA}$ & 14.64 \\
\hline $18: 1 n 9$ & $21.19 \pm 0.45$ \\
\hline$\sum \mathrm{MSFA}$ & 21.19 \\
\hline $18: 2 \mathrm{n} 6$ & $55.49 \pm 1.66$ \\
\hline 18:3n3 & $8.67 \pm 0.22$ \\
\hline$\sum \mathrm{PUFA}$ & 64.16 \\
\hline Total: & 100 \\
\hline \multicolumn{2}{|c|}{$\begin{array}{l}\sum \text { SFA, sum of unsaturated; } \sum \text { MUFA, } \\
\text { sum of monounsaturated; } \sum \text { PUFA, sum of } \\
\text { polyunsaturated. } \\
\text { Values are expressed by mean value } \pm \\
\text { standard error }(\mathrm{n}=2) \text {. Fatty acids that were } \\
\text { less than } 1 \% \text { were omitted }\end{array}$} \\
\hline
\end{tabular}

with data reported by Navam et al. (2014) on snacks formulated with fortified cereals with different percentages of soybeans. Ash content is also in accordance with the okara content added in each case. Veronica, Olusola and Adebowale (2006), reported similar values of ash in maize-based snacks with defatted soybean. The protein content is in the range of 15 to $19 \%$, higher than the $11 \%$ reported in okara and wheat snacks by Katayama and Wilson (2008) and the $12 \%$ reported by Ostermann-Porcel et al. (2017) in gluten-free cookies developed using okara and commercial manioc flour. On the other hand, this value was in the range of fortified corn tortilla preparations with $20-25 \%$ okara reported by Waliszewski et al. (2002). The snacks with greatest content of okara in the formulation (G1 and G2), showed the lowest total carbohydrates and the highest fibre, protein, and fat content. Dietary fibre plays an important role in many physiological processes and in the prevention of diseases of different origin. Therefore, daily intake of food rich in dietary fibre is important to reduce or regulate plasma cholesterol and triacylglycerol levels and to promote health. Table 3 also shows the results obtained for caloric value in each sample. A wide range of variation for energy levels for cereal bars (from 72.8 to 321.70 kcal.100 $\mathrm{g}^{-1}$ ) has been reported in the literature (Dutcosky, Grossmann, Silva \& Welsch, 2006; Gutkoski, Maria de Almeida Bonamigo, Marli de Freitas Teixeira \& Pedó, 2007). Also, energy level of $385.95 \mathrm{kcal} .100 \mathrm{~g}^{-1}$ of bars with high content of rice bran has been reported by Garcia, Lobato, Benassi and Soares Junior (2012). The energy level of the snack developed in the present work is in accordance with the levels reported in literature. On the other hand, the ingredients used in the formulation allowed obtaining products with low caloric value, since a $20 \mathrm{~g}$ for portion was calculated.

Regarding the fatty acid profile all the products fortified showed values of EPA and DHA according to the contents of fish oil used for enrichment. The predominant fatty acid was and DHA (C22:6), followed by oleic acid (C18:1), palmitic acid (C16:0) and EPA (C20:5). Recommendations concerning the daily intake of n-3 fatty acids fluctuate about 500mg of EPA + DHA in the form of food or supplements (Kris-Etherton, Grieger \& D Etherton, 2009; Simopoulos, 2002). EPA is the precursor of prostaglandins, thromboxanes and leukotrienes, and DHA is a component of the phospholipid membrane of the brain and cells of the retina, consequently, both fatty acids are essential for human health, showing significant effect in the prevention of cardiovascular diseases and the development of cognition respectively (Fournier et al., 2007; Zhong, Madhujith, Mahfouz \& Shahidi, 2007). Its benefits on human health have motivated, in recent decades, the development of products with its incorporation as additives, emulsions or capsules (Bermudez-Aguirre \& Barbosa-Canovas, 2011; Kolanowski \& Laufenberg, 2006; Ye, Cui, Taneja, Zhu \& Singh, 2009). According to the results obtained, it can be expected that snacks fortified with emulsion and capsulated might provide 126 and $51 \mathrm{mg}$ of EPA and DHA, which is approximately the $25 \%$ and $10 \%$ respectively of the omega-3 recommended minimal daily intake (Kris-Etherton et al., 2009; Simopoulos, 2002). 
Novel Snacks produced with Okara fortified with Omega-3 |SI91

Table 3: Nutritional value of okara snacks

\begin{tabular}{|c|c|c|c|c|c|c|}
\hline Sample & G1 & G2 & G3 & G4 & G5 & G6 \\
\hline$\%$ Moisture $^{a}$ & 18.55 & 18.63 & 15.25 & 14.25 & 13.49 & 12.91 \\
\hline$\% \mathbf{A s h}^{a}$ & 2.58 & 2.77 & 2.58 & 0.71 & 2.42 & 2.50 \\
\hline$\%$ Protein $^{a}$ & 19.36 & 18.98 & 17.34 & 15.49 & 17.64 & 17.31 \\
\hline$\%$ Fat $^{a}$ & 26.47 & 25.29 & 21.83 & 21.18 & 22.03 & 21.93 \\
\hline \%Carbohydrates ${ }^{a}$ & 12.76 & 13.76 & 19.92 & 23.71 & 20.06 & 19.81 \\
\hline$\%$ Fibre & 20.27 & 20.55 & 23.08 & 24.66 & 24.36 & 25.54 \\
\hline$\% \mathrm{Kcal}^{a}$ & 366.72 & 358.58 & 345.51 & 347.42 & 349.07 & 345.85 \\
\hline $\mathrm{Kcal}^{a}(20 \mathrm{~g})$ & 73.34 & 71.71 & 69.10 & 69.48 & 69.81 & 69.17 \\
\hline
\end{tabular}

\subsection{Sensory analysis}

Results of acceptance sensory studies are shown in Figure 3. Only the snacks formulated with the same rate of rice and okara were submitted for sensory analysis (G3, G5 and G6). According to the total sensory scores, all the samples exhibited great acceptable sensory characteristics. As regards to the flavour, odour and colour there were no statistical differences among the formulations. According to the descriptive sensory scores, the samples exhibited some differences in their characteristics (Table 3).

On the topic of the flavour, the snack without Omega-3 was the one that most evidenced a taste of rice. The other snacks were not rated as rice flavoured. The emulsion-enriched snacks were the most difficult to qualify in terms of taste, some panellists indicated this snack as sweet, others as salty and also undefined flavour was mentioned. The snack enriched with capsules was the only one that threw fishy taste, and in some cases without defining. The smell was similarly qualified. In this case, the snack without enriching was described as smelling like rice, although in some cases the 3 snacks were rated as having a soy smell. The snack enriched with capsules was the only one qualified with the smell of fish, and in some cases the qualification with fried odour was added.

Analysing the effect of snacks enrichment with Omega-3 on colour parameters change, results have shown an increase the brown tonality but no differences were detected between emulsion and capsulated fish oil.

Results showed that, in consumer preference tests, all samples presented a good acceptability. However, the order of preference by the panellists was G5 > G6.

\section{Conclusion}

Even though okara is a by-product, it contains many beneficial components from soybean. In this study, it was determined that okara can be used as ingredient to prepare snacks with acceptable chemical and sensory qualities. The snacks fortified showed a free fatty acid profile with high content of EPA and DHA. Also, all the snacks formulated showed high levels of protein and the ingredients used in the formulation allowed obtaining products with low caloric value. Even though this study has been focused on okara snacks fortification, the proposed approach could offer an interesting way to effectively incorporate oils rich in Omega-3 fatty acids into other kind of cereal bars. According to the total sensory scores, the samples exhibited acceptable characteristics among consumer panel members. In conclusion, it has been demonstrated that the incorporation of okara in snack foods fortified with Omega-3 from fish by-products resulted in significant improvements in the nutritional value of the products, whereas provide new alternatives for both by-products marketability and help in reducing environmental wastes. 


\section{References}

AOAC. (1984). Official Methods of Analysis Association of Official Analytical Chemists, Washington DC. AOAC INTERNATIONAL 14th Ed.

AOAC. (1990). Official Methods of Analysis Association of Official Analytical Chemists, Washington DC. AOAC INTERNATIONAL 16th Ed.

Bermudez-Aguirre, D. \& Barbosa-Canovas, G. V. (2011). Quality of selected cheeses fortified with vegetable and animal sources of omega-3. LWT-Food Science and Technology, 44(7), 1577-1584. doi:10.1016/j.lwt. 2011.01.023

Bligh, E. L. G. \& Dyer, W. J. A. (1959). A rapid method of total lipid extraction and purification. Canadian journal of biochemistry and physiology, 37, 911-7. doi:10.1139/o59099

Dapčević Hadnađev, T., Torbica, A. \& Hadnadev, M. (2013). Influence of buckwheat flour and carboxymethyl cellulose on rheological behaviour and baking performance of gluten-free cookie dough. Food and Bioprocess Technology, 6 . doi:10.1007/s11947-012-0841-6

Drake, M. A. (2007). Invited review: Sensory analysis of dairy foods. Journal of Dairy Science, 90(11), 4925-4937. doi:10.3168/ jds.2007-0332

Dutcosky, S. D., Grossmann, M. V. E., Silva, R. S. S. F. \& Welsch, A. K. (2006). Combined sensory optimization of a prebiotic cereal product using multicomponent mixture experiments. Food Chemistry, 98(4), 630-638. doi:10.1016/j.foodchem.2005.06. 029

FAO/WHO. (2011). Dietary protein quality evaluation in human nutrition Report of an FAO Expert Consultation FAO FOOD AND NUTRITION PAPER 92, pp 66.

Ferguson, L. R., Smith, B. G. \& James, B. J. (2010). Combining nutrition, food science and engineering in developing solutions to inflammatory bowel diseases-omega-3 polyunsaturated fatty acids as an example. Food ES Function, 1(1), 60-72. doi:10.1039/ c0fo00057d
Fournier, V., Destaillats, F., Hug, B., Golay, P.-A., Joffre, F., Juaneda, P., . . Berdeaux, O. (2007). Quantification of eicosapentaenoic and docosahexaenoic acid geometrical isomers formed during fish oil deodorization by gas-liquid chromatography. Journal of Chromatography A, 1154(1-2), 353-359. doi:10.1016/j.chroma.2007.03.099

Friedman, M. \& Brandon, D. L. (2001). Nutritional and health benefits of soy proteins. Journal of Agricultural and Food Chemistry, 49(3), 1069-1086. doi:10.1021/ jf0009246

Frost, D. J., Adhikari, K. \& Lewis, D. S. (2011). Effect of barley flour on the physical and sensory characteristics of chocolate chip cookies. Journal of Food Science and Technology - MYSORE, 48(5), 569-576. doi:10. 1007/s13197-010-0179-X

Garcia, M. C., Lobato, L. P., Benassi, M. d. T. \& Soares Junior, M. S. (2012). Application of roasted rice bran in cereal bars. Ciencia e Tecnologia de Alimentos, 32(4), 718-724. doi:10.1590/S0101-20612012005000096

Genovese, M. I. \& Lajolo, F. A. (2002). Isoflavones in soy-based foods consumed in brazil: Levels, distribution, and estimated intake. Journal of Agricultural and Food Chemistry, 50(21), 5987-5993. doi:10. 1021/jf0202990

Guimaraes, R. M., Silva, T. E., Lemes, A. C., Favaro Boldrin, M. C., Pereira da Silva, M. A., Silva, F. G. \& Egea, M. B. (2018). Okara: A soybean by-product as an alternative to enrich vegetable paste. $L W T$ Food Science and Technology, 92, 593-599. doi:10.1016/j.lwt.2018.02.058

Gutkoski, L., Maria de Almeida Bonamigo, J., Marli de Freitas Teixeira, D. \& Pedó, I. (2007). Desenvolvimento de barras de cereais à base de aveia com alto teor de fibra alimentar. Ciencia e Tecnologia de Alimentos-ciencia Tecnol Aliment, 27. doi:10.1590/S0101-20612007000200025

Guzman Tituaña, E. D. (2018). Obtención de una bebida proteica a base de soya (glycine max) y naranjilla (solanum quitoense) (B.S. thesis, Quito, 2018.). Retrieved from http : / / bibdigital . epn . edu . ec / handle / $15000 / 19333$ 
Novel Snacks produced with Okara fortified with Omega-3 |SI93

He, F. \& Chen, J.-Q. (2013). Consumption of soybean, soy foods, soy isoflavones and breast cancer incidence: Differences between chinese women and women in western countries and possible mechanisms. Food Science and Human Wellness, 2. doi:10.1016/j.fshw.2013.08.002

Hoogenkamp, H. (2007). The soy industry's lovehate relationship with meat. Meat Intl, $17(2), 8-11$.

Iafelice, G., Caboni, M. F., Cubadda, R., Di Criscio, T., Trivisonno, M. C. \& Marconi, E. (2008). Development of functional spaghetti enriched with long chain omega-3 fatty acids. Cereal Chemistry, 85(2), 146151. doi:10.1094/CCHEM-85-2-0146

Kanojia, V., Singh, M., M. Khandelwal, B. \& Azam, M. (2016). Effect of single screw extrusion parameters on textural properties of rice based expanded snacks enriched with okara. Indian Journal of Science and Technology, 9. doi:10.17485 / ijst / 2016 / v9i22/88437

Katayama, M. \& Wilson, L. A. (2008). Utilization of okara, a byproduct from soymilk production, through the development of soy-based snack food. Journal of Food Science, 73(3), S152-S157. doi:10.1111/j . 1750-3841.2008.00662.x

Kolanowski, W. \& Laufenberg, G. (2006). Enrichment of food products with polyunsaturated fatty acids by fish oil addition. European Food Research and Technology, 222(3-4), 472-477. doi:10. 1007 / s00217005-0089-8

Kolanowski, W. \& Weissbrodt, J. (2008). Possibilities of fisherman's friend type lozenges fortification with omega-3 lc pufa by addition of microencapsulated fish oil. Journal of the American Oil Chemists Society, 85(4), 339-345. doi:10.1007/s11746008-1203-4

Kris-Etherton, P., Grieger, J. \& D Etherton, T. (2009). Dietary reference intakes for dha and epa. Prostaglandins, leukotrienes, and essential fatty acids, 81, 99-104. doi:10 . 1016/j.plefa.2009.05.011

Li, T., Zhong, J.-Z., Wan, J., Liu, C.-M., Le, B.-Y., Liu, W. \& Fu, G.-M. (2013). Effects of micronized okara dietary fiber on cecal microbiota, serum cholesterol and lipid levels in balb/c mice. International Journal of Food Sciences and Nutrition, 64(8), 968-973. doi:10 . 3109 / 09637486. 2013.809705

Meng, X., Threinen, D., Hansen, M. \& Driedger, D. (2010). Effects of extrusion conditions on system parameters and physical properties of a chickpea flour-based snack. Food Research International, 43(2, SI), 650-658. doi:10.1016/j.foodres.2009.07.016

Merritt, R. J. \& Jenks, B. H. (2004). Safety of soy-based infant formulas containing isoflavones: The clinical evidence. Journal of Nutrition, 134(5), 1220S-1224S. 5th International Symposium on the Role of Soy in Preventing and Treating Chronic Disease, Orlando, FL, SEP 21-24, 2003.

Messina, M. J. \& Loprinzi, C. L. (2001). Soy for breast cancer survivors: A critical review of the literature. Journal of Nutrition, 131 (11, S), 3095S-3108S. 11th Annual Research Conference on Diet, Nutrition and Cancer, WASHINGTON, D.C., JUL 16-17, 2001.

Navam, S. H., Tajudini, A. L., Srinivas, J. R., Sivarooban, T. \& Kristofor, R. B. (2014). Physio-chemical and sensory properties of protein-fortified extruded breakfast cereal/snack formulated to combat protein malnutrition in developing countries. Journal of Food Processing and Technology, 5(8), 359. doi:10.4172/2157-7110. 1000359

O'Brien, R. D. \& Timms, R. E. (2004). Fats and oils-formulating and processing for applications. European Journal of Lipid Science and Technology, 106(7), 451-451.

Ostermann-Porcel, M. V., Quiroga-Panelo, N., Rinaldoni, A. N. \& Campderros, A. E. (2017). Incorporation of okara into glutenfree cookies with high quality and nutritional value. Journal of Food Quality. doi: $10.1155 / 2017 / 4071585$

Randall, E. L. (1974). Improved method for fat and oil analysis by a new process of extraction. Journal of the Association of Official Analytical Chemists, 57(5), 1165-1168.

Rhee, K. S., Kim, E. S., Kim, B. K., Jung, B. M. \& Rhee, K. C. (2004). Extrusion 
of minced catfish with corn and defatted soy flours for snack foods. Journal of Food Processing and Preservation, 28, 288-301. doi:10.1111/j.1745-4549.2004.23069.x

Simopoulos, A. P. (2002). The importance of the ratio of omega-6/omega-3 essential fatty acids. Biomedicine $\&$ Pharmacotherapy, 56 (8), 365-379. doi:10.1016/S07533322(02)00253-6

Tie Su, S. I., Pedroso Yoshida, C. M., ContrerasCastillo, C. J., Quinones, E. M. \& Venturini, A. C. (2013). Okara, a soymilk industry by-product, as a non-meat protein source in reduced fat beef burgers. Food Science and Technology, 33(1), 52-56.

Tovar, A. R., Murguia, F., Cruz, C., HernandezPando, R., Aguilar-Salinas, C. A., PedrazaChaverri, J., ... Torres, N. (2002). A soy protein diet alters hepatic lipid metabolism gene expression and reduces serum lipids and renal fibrogenic cytokines in rats with chronic nephrotic syndrome. Journal of Nutrition, 132(9), 2562-2569.

Turhan, S., Temiz, H. \& Sagir, I. (2007). Utilization of wet okara in low-fat beef patties. Journal of Muscle Foods, 18(2), 226-235. doi:10.1111/j.1745-4573.2007.00081.x

USDA. (2007). 7united states department of agriculture. dairy market news0. Retrieved from http://www.ams.usda.gov/ AMSv1 . 0 / ams . fetchTemplateData . do ? template $=$ TemplateA $\% 5 \mathrm{C} \&$ navID = CommodityAreas $\% \quad 5 \mathrm{C} \quad \&$ leftNav $=$ CommodityAreas $\% 5 \mathrm{C} \&$ page $=$ DairyLandingPage $\% 5 \mathrm{C} \&$ description $=$ $\%$ 20Dairy\%5C\&acct=dairy

Vanegas Perez, L., Restrepo Molina, D. \& Lopez Vargas, J. H. (2009). Characteristics of the drinks with soybean protein. Revista Facultad Nacional de Agronomia, Medellin, 62, 5165-5175.

Verma, V. \& Patel, S. (2013). Value added products from nutri-cereals: Finger millet (eleusine coracana). Emirates Journal of Food and Agriculture, 25(3), 169-176. doi:10.9755/ejfa.v25i3.10764

Veronica, A. O., Olusola, O. O. \& Adebowale, E. A. (2006). Qualities of extruded puffed snacks from maize/soybean mix- ture. Journal of Food Process Engineering, 29(2), 149-161.

Vong, W. C. \& Liu, S.-Q. (2016). Biovalorisation of okara (soybean residue) for food and nutrition. Trends in Food Science \& Technology, 52, 139-147. doi:10.1016/j.tifs.2016. 04.011

Wachiraphansakul, S. \& Devahastin, S. (2007). Drying kinetics and quality of okara dried in a jet spouted bed of sorbent particles. LWT-Food Science and Technology, 40, 207-219. doi:10.1016/j.lwt.2005.11.010

Waliszewski, K. N., Pardio, V. \& Carreon, E. (2002). Physicochemical and sensory properties of corn tortillas made from nixtamalized corn flour fortified with spent soymilk residue (okara). Journal of Food Science, 67(8), 3194-3197. doi:10.1111/j.1365-2621. 2002.tb08881.x

Ye, A., Cui, J., Taneja, A., Zhu, X. \& Singh, H. (2009). Evaluation of processed cheese fortified with fish oil emulsion. Food Research International, 42(8), 1093-1098. doi:10 . 1016/j.foodres.2009.05.006

Yupa, I. \& Claribel, G. (2015). Efecto de diferentes grasas con omega 3 en la elaboración de una bebida hidratante a partir del suero de leche (B.S. thesis, Escuela Superior Politécnica de Chimborazo).

Zhong, Y., Madhujith, T., Mahfouz, N. \& Shahidi, F. (2007). Compositional characteristics of muscle and visceral oil from steelhead trout and their oxidative stability. Food Chemistry, 104(2), 602-608. doi:10.1016/j.foodchem.2006.12.036 